DR. MARINA CORRÊA SCALON (Orcid ID : 0000-0003-2069-8226)

Article type : Research article

Dave Roberts

Editor: Dr. Roberts

\title{
Diversity of functional trade-offs enhances survival after fire in Neotropical savanna species
}

Marina Corrêa Scalon ${ }^{1,2 *}$, Fabricius Maia Chaves Bicalho Domingos ${ }^{3}$, Wesley Jonatar Alves da $\mathrm{Cruz}^{4}$, Ben Hur Marimon Júnior ${ }^{4}$, Beatriz Schwantes Marimon ${ }^{4}$, Imma Oliveras $^{1}$

${ }^{1}$ Environmental Change Institute, School of Geography and the Environment, University of Oxford, Oxford OX1 3QY, UK

${ }^{2}$ Current address: Programa de Pós-graduação em Ecologia e Conservação, Universidade Federal do Paraná, Curitiba, PR, 81531-990, Brazil

${ }^{3}$ Departamento de Zoologia, Universidade Federal do Paraná, Curitiba, PR, 81531-990, Brazil

${ }^{4}$ Programa de Pós-graduação em Ecologia e Conservação, Universidade do Estado de Mato Grosso

- UNEMAT, Nova Xavantina, MT, 78690-000, Brazil

*Corresponding authors e-mail: marina_scalon@yahoo.com.br (+44 (0) 1865 275848)

ORCID ID 0000-0003-2069-8226

Running title: Fire recovery strategies of savanna trees

Funding Information: Authors wish to acknowledge funding through the Science without Borders grant to IO PVE/CAPES (PVE223221/2014) that funded a post-doctoral fellowship to MCS and CNPq/PELD (441244/2016-5). BSM is a recipient of a CNPq Research Productivity fellowship (305029/2015-0).

This article has been accepted for publication and undergone full peer review but has not been through the copyediting, typesetting, pagination and proofreading process, which may lead to differences between this version and the Version of Record. Please cite this article as doi: 10.1111/JVS.12823

This article is protected by copyright. All rights reserved 


\section{Abstract}

Questions. What are the trade-offs and /or associated syndromes within and between fire-associated traits? Does bud protection relate to bark properties and tree resprouting ability? Which traits will influence post-fire tree survival (mortality rate and topkill) and tree recovery (canopy recovery and resprouting volume)? Do species with different leaf phenology have the same ecological strategies to survive and recover from fire?

Location. Tree community in a Neotropical savanna.

Methods. For each of the 24 most abundant species, we characterised the trade-offs among bud protection, bark traits, mortality, canopy recovery and topkill, and resprouting strategies in both a burned and adjacent unburned area of Cerrado vegetation.

Results. Species with unprotected buds had a higher risk of dying, while high bud protection was associated to the ability to resprout from both the canopy and the base of the tree. We found three major trade-offs defined by bark traits and plant properties. Cerrado woody species invest in either (1) high inner bark thickness and bark moisture, or (2) fast growth rate, height and bark density, or (3) thick outer bark and high wood density with high bud protection.

Conclusions. Cerrado species show different sets of fire-related traits that seem to be important for both individual survival and community assembly. Here, we report these trade-offs for Neotropical savannas, and our findings also shed light on how changes in fire regime may favour different groups of species, leading to changes in plant communities over time.

Keywords: bark, bud protection, Cerrado, leaf phenology, mortality, resprouting, topkill, random forest. 


\section{Introduction}

It is well known that fire is a major driver of tree dynamics in tropical savannas, and also an important environmental filter underpinning the mechanisms of community assembly (Lehmann et al., 2011). In fire prone environments, tree survival depends on a combination of fire-associated factors (e.g., fire intensity and frequency; Bond \& Keeley, 2005), properties (e.g. growth rates, Hoffmann et al., 2012) and functional traits (e.g. resprouting capacity, bark thickness, bud protection, underground storage organ (Perez-Harguindeguy et al. 2013; Lawes \& Clarke, 2011; Hoffmann et al., 2012; CharlesDominique et al., 2015, Pausas et al. 2018). Among these, the ability of a plant species to resprout after topkill (i.e., destruction of most of its above-ground biomass) or to maintain the main stem alive and recover its canopy rapidly are the key strategies for its persistence in ecosystems where fires are common (Vesk, 2006; Lawes \& Clarke, 2011; Clarke et al., 2013).

Although the role of resprouting as a post-fire regeneration strategy is well established, research investigating bud protection strategies has only been recently developed (Burrows, 2002; Charles-Dominique et al., 2015). Bud protection is defined as the location of buds in relation to the bark layer, varying from completely exposed buds, located at the surface of the stems, to completely protected buds, covered by all bark layers; with intermediate levels of protection in between these extremes (Burrows et al., 2010; Burrows \& Chisnall, 2016).

Considering carbon investment balance, the trade-off between investing in bark thickening instead of plant processes such as growth or reproduction is well understood (Jackson et al., 1999; Hoffmann et al., 2009; Keeley et al., 2011; Lawes et al., 2013). Investing in either early height growth or early bark growth are potential strategies to escape or endure fire (Gignoux et al., 1997; Hoffmann et al., 2012). However, bark is not only related to fire-escape strategies (Hoffmann \& Solbrig, 2003), but also has many different functions, such as mechanical support (Niklas, 1999), $\mathrm{CO}_{2}$ assimilation (Aschan \& Pfanz, 2003); herbivory protection (Romero \& Bolker, 2008); and storage of water and carbohydrates (Scholz et al., 2007). Bark is composed by an inner living portion, which includes the innermost area of the periderm, and a non-living outer portion that is composed of dead cells. Across species, there is a wide variation in total and relative amounts of inner and outer bark, likely reflecting trade-offs between different bark functions (Rosell et al., 2014). For example, inner bark is important for water storage and photosynthesis, while outer bark seems to be more related to 
protection against fire and physical damage (Rosell et al., 2014). However, despite the two very distinct functional roles of inner and bark thickness, most studies only use total bark thickness as a fire-protection trait and therefore the relative roles on these two distinct portions of bark on conferring fire protection remains unclear. There is a potentially important trade-off between investing on a thick bark to protect a stem against fire, or investing on a thinner bark, where light penetration depth and $\mathrm{CO}_{2}$ low-permeability could promote high rates of stem recycling photosynthesis, and therefore support hydraulic function in the sapwood (Cernusak \& Hutley, 2011; Rosell et al., 2014; Cernusak \& Cheesman, 2015). In the Cerrado, the Brazilian savanna, this trade-off can be particularly important because the vegetation is naturally subjected to strong climate seasonality and frequent fires (Coutinho, 1990). The Cerrado seasonal drought-fire relationship might also be linked to plant resource use strategies, which can also influence tree survival, such as different leaf phenology (Scalon et al., 2017).

Most of the traditionally measured functional traits are focused directly around resource economy and fluxes, and not usually on disturbance response traits (Driscoll et al., 2010). It is still unknown how different traits (i.e., resprouting ability, bud protection, bark inner and outer thickness) and ecological strategies related to carbon use (i.e., growth rate and leaf phenology pattern) are selected and coordinated in savanna woody plants responding to fire (Cardoso et al., 2016).

Moreover, there are yet no studies on bud protection strategies for the Cerrado, and therefore it is still unknown how they relate to other fire-related traits in the Cerrado vegetation. This study investigates how fire associated functional traits and properties (i.e., bud protection, resprouting capacity, bark traits and growth investment) affect tree survival (i.e., mortality and topkill) after fire in Cerrado vegetation. We aimed at identifying whether there are trade-offs (i.e. resources being primarily allocated to a specific trait due to the impossibility to optimize two traits simultaneously) and/or firerelated trait syndromes (i.e. synergetic interactions between multiple co-varying traits; Agrawal, 2007 ) in the 24 most abundant species growing in the same Cerrado area. Specifically, we set out to answer the following questions:

(I) What are the trade-offs and /or associated syndromes within fire-associated traits? Does bud protection relate to bark properties and tree resprouting ability? As shown for African savannas (Charles-Dominique et al., 2015), we expect that bud protection will be related to 
type of resprouting and tree survival after fire in the Brazilian savanna. Specifically, we expect that species with more protected buds will show higher canopy recovery and aerial resprouting, and lower topkill and mortality rates compared to species with exposed buds.

(II) What are the trade-offs and/or associated syndromes between fire-associated traits and growth? We hypothesize that there will be a trade-off between growth and other fireassociated traits (bud protection and bark traits), so that plants with lower growth rates will invest significant amounts of resources in fire-defence (Jackson et al., 1999; Hoffmann \& Solbrig, 2003; Hoffmann et al., 2012).

(III) Which traits will influence post-fire tree survival (mortality rate and topkill) and tree recovery (canopy recovery and resprouting volume)? Do species with more protected buds have higher rates of survival? Based on previous studies in fire-prone environments (Hoffmann et al., 2009; Lawes et al., 2011a; Brando et al., 2012), we predict that barkrelated traits, especially total bark thickness, will play a major role in tree survival and recovery after fire, because bark insulation properties protects the cambium from lethal temperatures (Lawes et al., 2011b).

(IV) Do species with different leaf phenology have the same ecological strategies to survive and recover from fire? We expect that a late-dry season fire will be more detrimental to deciduous species, because they would have just flushed new leaves before the fire, having potentially less carbohydrate storage. Thus, we expect deciduous species to show lower percentage of canopy recovery and lower maximum resprouting volume, but higher mortality and higher topkill rates.

To the best of our knowledge, this is the first study to combine bud protection strategies together with bark traits, growth rates and resprouting capacity to uncover plant ecological strategies that individuals use to survive a fire event in a tropical savanna environment.

\section{Material and Methods}

The study was conducted on two neighbouring areas of typical cerrado vegetation (cerrado sensu stricto), one that burned in August 2016 and another without historical records or signs of fire. Both areas are located in the Bacaba Municipal Park at Nova Xavantina, Mato Grosso, Brazil (14²43'122 S

This article is protected by copyright. All rights reserved 
and $52^{\circ} 21^{\prime} 36.7^{\prime \prime}$ W). Fieldwork was carried out during October 2016 to January 2017. Both areas had permanent 1 ha plots, belonging to the long-term project PELD-CNPq Amazonia-Cerrado transition: ecological and social-environmental basis to conservation, with three vegetation censuses (2009, 2012, 2014) available upon request at the ForestPlots database (forestplots.net). Each census recorded the diameter at breast height (DBH) and tree height for all individuals $>5 \mathrm{~cm}$ of diameter at $30 \mathrm{~cm}$ from the soil $\left(\mathrm{D}_{30}\right)$. All individuals were identified to the species level. The unburned area was only separated from the burned area by an unpaved road that acted as a firebreak. For the purpose of this study, we selected 24 species of the local community corresponding to over $80 \%$ of basal area of both unburned and burned plots, and therefore broadly representative of the local vegetation type (Appendix S1). Leaf phenology patterns were found in the literature (Appendix S1). Absolute growth rate was calculated based on annual DBH increment $\left(\mathrm{mm} \mathrm{y}^{-1}\right)$ from 2009 to 2014, averaged for each species.

The fire was intentional and occurred in the mid-to-late dry season (August 2016) and corresponded to a typically high intensity and fast rate of spread Cerrado fire (Appendix S2). In the burned plots, we sampled individuals three months after the fire, and classified individuals as being dead, top-killed or alive, on at least five individuals of each species (totalling 279 individuals; mean \pm $\mathrm{sd}=11.6 \pm 6.5$ individuals of each species). An individual was dead when its aboveground biomass was dead and did not resprout. An individual was top-killed when its aboveground biomass was dead but presented basal and/or underground resprouting. Dead and top-killed individuals were checked for living xylem and revisited 6 months after fire to confirm stem death. Finally, alive trees were those that had survived the fire (i.e. alive aboveground biomass) regardless of resprouting type. We classified resproutings into four categories (not mutually exclusive): aerial (canopy), stem (resprouting from the main stem), basal (on the ground), and underground (Appendix S3). For each resprouted individual, we counted the total number of shoots, total number of leaves, maximum shoot height/length and the maximum shoot diameter. We calculated the maximum resprouting volume (MRV) to estimate post-fire vigour, according to Knox and Clarke (2011), as MRV = ((diameter of the tallest shoot $/ 2)^{2} \times$ shoot height).

In the unburned area, during the peak of the wet season (December 2016 and January 2017), we collected $\sim 2 \mathrm{~cm}^{2}$ bark samples at $30 \mathrm{~cm}$ from the soil on five individuals per species, for the 24

This article is protected by copyright. All rights reserved 
selected species. From the same individuals we also collected five leaves and five twigs of $\geq 1 \mathrm{~cm}$ diameter. Immediately after collection, we measured inner and outer bark thickness with digital callipers $( \pm 0.01 \mathrm{~mm})$, and measured fresh weight and volume using a digital scale $( \pm 0.001 \mathrm{~g})$. In fissured bark species, measurements were taken from the ridges to consider the maximum bark thickness. Dry weight and bark density were obtained after oven-drying the samples for 5 days at 70 ${ }^{\circ} \mathrm{C}$. Total bark thickness was calculated as the sum of inner and outer bark thickness. We then calculated the relative bark thickness (inner, outer, total) for both the stem and the twig, as the ratio between bark thickness and the stem/twig radius x 100 (Lawes et al. 2013). Although the vegetation structure in the area is very homogeneous with no relevant individual variation in size (Appendix S1), we controlled for individual size by using relative bark thickness values for all analyses in this study. Tree height averaged $3.13 \mathrm{~m}$ ranging from 2.03 to $4.35 \mathrm{~m}$ within species (Appendix S4), and the fire affected the canopy of all trees in the area, irrespective of the tree height (see Appendix S2b), where leaves were mostly charred or scorched and abscised 2-3 days after fire due to the heat damage.

We collected five leaves per individual and measured leaf areas for the leaf laminas with petiole (and rachis for compound leaves) by scanning them on a flatbed scanner (Canon Lide 110®) and measuring the leaf area with the software Image $J$ (Abràmoff et al., 2004). Dry mass was measured after oven drying leaves at $70^{\circ} \mathrm{C}$ until constant weight. Specific leaf area (SLA) was calculated by dividing the fresh area by the dry mass.

In the sampled twigs, we identified epicormic buds by small irregularities on the bark surface, according to Burrows et al. (2010) and accessed buds by a longitudinal cut. Twig sections where buds were identified were photographed using a Zeiss ${ }^{\circledR}$ Stemi DV4 camera equipped stereomicroscope. We classified the bud according to Burrows et al. (2010) and Charles-Dominique et al. (2015) using a qualitative criterion: 0 for completely exposed buds; 1 for emerging buds but protected meristem; 2 for buds allocated inside depressions in the bark; and 3 for buds completely protected under the bark (Fig. 1). It might be important to note that (I) we only assessed primary buds, and accessory buds might differ in the degree of protection; (II) only bark bud protection was studied, and the eventual protection by bud scales was not considered; and (III) buds were identified only in $\sim 1 \mathrm{~cm}$ diameter twigs, and different diameter branches may show distinct bud protection categories.

This article is protected by copyright. All rights reserved 


\section{Data analysis}

All analyses were performed using software R v. 3.4.0 (R Development Team, 2017). Data were tested and log-transformed when appropriate to satisfy normality assumptions (Shapiro-Wilk test). All tests were performed at the species level. To understand how fire-associated traits are related (question I), and to test for differences in distinct leaf phenology groups (question IV), we compared bark trait differences between distinct bud protection categories and between different phenological groups (deciduous, briefly-deciduous and evergreen species) using univariate ANOVA to test for individual effect of the response variable (Quinn \& Keough, 2002). Differences were considered to be significant when $P$-value was $<0.05$ after post-hoc Tukey tests for unequal sample sizes (Zar, 1999). For all variables that were not normally distributed (i.e., resprouting strategies, topkill, canopy recovery and mortality, expressed as percentage of individuals within species) we used KruskalWallis tests.

To understand how bud protection related to tree resprouting ability (question I), firstly, we used a correspondence analysis (CA) to explore the relationship between bud protection and species post-fire responses (e.g., mortality, top-kill and resprouting strategies) using the package FactoMineR (Lê et al., 2008). We grouped post-fire responses strategies according to the mechanism of resprouting as (I) epicormic (apical and stem resprouting only), (II) hypogeal (basal and underground resprouting only) and (III) epi+hypogeal (a combination of epicormic and hypogeal resprouting together). Bud protection categories were considered four distinct categorical variables and CA was performed with the percentage of individuals showing the post-fire responses described above per bud protection class. Secondly, to identify potential sets of Cerrado tree ecological strategies, we performed a cluster analysis to group species based on Euclidean distances according to fire-related traits using the package 'Nbclust' (Charrad et al., 2014). Finally, to understand the relationship between fire-related traits and growth (question II), we performed a principal component analysis (PCA) to explore multivariate associations among bark (e.g., bark thickness, bark density and bark water content) and species traits (e.g., height, growth rate, DBH, wood density and SLA). The PCA graphical representation was coloured according to the groups identified by the cluster analysis to show how these groups were spatially distributed in relation to the traits analysed. We also tested for bivariate trait associations using Pearson correlations. 
To investigate which traits better explained tree mortality, topkill, resprouting volume and canopy recovery (question III) we used Random Forest (RF) analysis for variable selection using the R package VSURF (Genuer et al., 2015). In this framework, variable selection is based on the quantification of a Variable Importance (VI) score, which is calculated considering the increase in the mean square error (i.e., out-of-bag error, OOB) of a tree in the forest when the observed values of a particular variable are permuted in the OOB samples (Genuer et al., 2010). The variable selection is performed in three steps, where the first one eliminates irrelevant variables, the second selects all variables that are related to the response variable, and the third refines this selection by eliminating variable redundancy (see Genuer et al., 2010 and Genuer et al., 2015 for more details). In summary, the variables are tested in a stepwise way using a sequence of RF models, where the variables are only added if the decrease in error is larger than a threshold. At the third step, this threshold is set to the mean of the absolute values of the OOB error between the RF models after and before the exclusion of each variable. Thus, at the final variable selection step, only the variables that are highly related to the response variable (and with low redundancy) are retained. We repeated this analysis four times using tree mortality, topkill, resprouting volume and canopy recovery as response variables, and all other measured variables as predictor variables.

\section{Results}

Trade-offs and associated syndromes within fire-associated traits

All measured traits (mean and range at species level) are shown in Appendix S4. Bud protection classification was generally very consistent across individuals and the categories showed similar proportions among species: a plurality of species (33\%) showed high bud protection (category 3, with buds completely covered by outer bark), followed by $25 \%$ of the species with emerging buds (category 2), 21\% species with buds allocated inside depressions of the bark (category 1) and 21\% showed no bud protection at all (category 0; Fig. 1, Appendix S1).

Species with buds in category 3 had the highest stem relative outer bark thickness, but the lowest stem relative inner bark thickness (Table 1). This difference in the proportion resulted in the highest stem relative bark thickness and the lowest relative bark water content (Table 1). There was

This article is protected by copyright. All rights reserved 
no difference between the distinct categories of bud protection in bark density or in twig relative bark thickness (Table 1).

Exploring these trade-offs further, the correspondence analysis (Fig. 2, Appendix S5) showed that trees with unprotected buds (category 0) had a higher risk of dying after fire. Species with low to moderate bud protection (categories 1 and 2) showed a higher association with underground and basal resprouting, suggesting that they might rely on the soil to act as a buffer and protect their buds, since canopy resprouting ability was lower. Species with buds completely protected by bark (category 3 ) exhibited a better chance to maintain the whole structure after fire, resprouting from both the canopy and the base, and showing lower mortality (Fig. 2). However, direct comparisons (Kruskal-Wallis tests, Appendix S6) failed to show these differences between resprouting strategies among different bud protection strategies, except for the higher proportion of species resprouting from both canopy and base being those with thicker bark.

\section{Trade-offs and/or associated syndromes between fire- and growth-associated traits}

Cluster analysis identified three major species groups according to the studied set of traits, and PCA analysis corroborated the relationship between key bark traits, tree properties and bud protection among the three groups (Fig. 3, Appendix S7). Although groups differed in resprouting strategies, there were no differences in relation to mortality, topkill or canopy recovery after fire (KruskallWallis, all $P$-value $>0.05$, Appendix S8).

Associations between fire-associated traits and growth were also revealed by the PCA analysis, where PC1 and PC2 combined explained 49.2\% of the total variation (Fig. 3, Appendix S9). The first axis reflected bark structure, suggesting a trade-off between the investment in outer and inner bark, and how inner bark thickness was positively associated with bark water content (Table 2). This trade-off occurred not only considering the main stem, but also for the twig bark structure. The PCA second axis was more associated to plant carbon allocation to different tree functions, representing the trade-off between plant growth, height and inner and outer bark density and the investment in bark thickness and wood density. Indeed, most of these trait relationships were statistically significant (Table 2, Pearson's correlation, $P<0.05$ ).

This article is protected by copyright. All rights reserved 


\section{Traits influencing post-fire survival and recovery}

The selected variables for the four RF analyses (i.e., tree mortality, topkill, resprouting volume and canopy recovery as response variables) were mostly in accordance with our hypothesis for tree survival and recovery (Table 3, Appendix S10). As expected, tree mortality was better explained by inner bark traits (main stem inner bark thickness and density), while topkill was better explained by both bark traits (outer bark water content) and intrinsic tree species properties (growth and phenological group). Similarly, resprouting volume was better explained by bark traits (twig total bark thickness and main stem inner bark thickness) and tree properties (SLA and Height), while canopy recovery was better explained by tree properties only (DBH, Height and SLA).

\section{Differences between phenology groups}

There was no difference between the three phenology groups in relation to bark investment (relative bark thickness, bark density or bark water content, Figure 4a-c) or in relation to resprouting behaviour (maximum resprouting volume, proportion of different resprouting types or canopy recovery, Figure 4d-i). However, while all phenology groups showed relatively low mortality rates (ranging from 3.66 to $9.03 \%$ ), briefly-deciduous species showed higher topkill rates, followed by deciduous species (Fig. 4j). Interestingly, evergreen species showed lower rates of topkill after fire (Fig. $4 \mathrm{j}$ ), and significantly higher growth rates associated with lower SLA (Fig. 4k and 41).

\section{Discussion}

Our results uncover the roles and relative importance of a unique set of fire-associated traits that provide species with the ability to survive and recover after fire. We investigated how bud protection, resprouting ability, bark traits and tree properties are combined as ecological strategies for 24 abundant tree species in a Neotropical fire-prone savanna. Contrary to our expectation (first working hypothesis), we found a significant relationship between bud protection, resprouting strategies and bark thickness traits. In this study, we confirmed that bud protection is related to resprouting in Cerrado species, with a remarkably similar pattern as the one observed by Charles-Dominique et al. (2015) in African savanna species. Here, as shown by our correspondence analysis, we found that species with (1) unprotected buds have a higher risk of dying; (2) low to medium bud protection are

This article is protected by copyright. All rights reserved 
more likely to resprout from the base; and (3) higher bud protection tend to resprout from both the canopy and the base, even though direct comparisons were not significant. The high variability of the data may have obscured some clear tendencies that have emerged, such as species with higher bud protection showing lower mortality and higher canopy recovery, identified by the correspondence analysis.

High bud protection was associated with thicker outer bark, thinner inner bark and low bark water content, while species with exposed buds and intermediate protection tended to show thicker inner bark and high bark water content. The association between bud protection, bark traits and tree properties was used to identify three major groups of species. Therefore, although we only observed fire responses to a single fire event, by evaluating the combination of plant traits, we propose a set of Cerrado tree ecological strategies for surviving and recovering after fire: (1) species investing in fast growth rates, height and diameter combined with high bark density; (2) species investing mainly in inner bark thickness and bark water content; or (3) species investing in thick outer bark, high wood density, SLA and high bud protection. As far as bud protection is considered, we found that only very protected buds were related with higher bark thickness, but especially with higher outer bark thickness, and there was not a clear pattern between the other bud protection categories. Moreover, there were no significant differences in mortality or recovery among the different species groups, meaning that the three strategies co-exist in the Cerrado woody plant community and are successful in post-fire recovery. Our findings generally agree, but also expand on the previous two major plant strategies to escape fire described for savannas, known as the 'lanky' (height growth) and the 'corky' (bark growth) strategies (Dantas \& Pausas 2013), adding another key strategy of investing in inner bark thickness and showing that these two previous described strategies involve the investment in other associated traits.

Furthermore, we identified a series of trade-offs and associated syndromes in woody Cerrado plants responses to fire. Two clear trade-offs emerged: investing in increased growth rate, height and bark density vs. investing in bark thickness and higher wood density; and investing in outer vs. inner bark. The choice between investing in growth and building a tall canopy vs. investing in thick insulating barks to resist fire is a relatively well explored plant strategy trade-off (Gignoux et al., 1997; Hoffmann et al., 2009; Keeley et al., 2011; Lawes et al., 2013, Souchie et al. 2017). A thick 
outer bark can provide protection to the phloem and cambium, so that bark thickness is usually thought to be the main factor explaining tree survival after fire. Hence, it is expected that taller trees with thinner barks will be associated to less intense fire systems (Gignoux et al., 1997) or high herbivory pressure (Bond et al., 2012), while thicker bark species to be more frequent if fire is more intense (Hoffmann et al., 2009; Rosell, 2016).

To the best of our knowledge, the trade-off between investing in inner versus outer bark has not been previously addressed (but see Rosell, 2016). Most studies to date have measured total bark thickness but have not investigated each bark portion separately (Lawes et al., 2011a; Lawes et al., 2011e; Hoffmann et al., 2012; Schafer et al., 2015), even though Rosell (2016) has recently brought to attention the importance of studying the different evolutionary drivers in both inner and outer regions of the bark. In this study, we found a strong positive relationship between inner bark thickness and bark water content. Although inner bark is expected to be associated with plant metabolism, reflecting water and carbohydrate storage (Rosell, 2016), Scholz et al. (2007) found a relatively small contribution of the bark to total stem water capacitance in Cerrado trees, suggesting that it may be more related to fire protection, conferring thermal insulation to the vascular cambium and sapwood. Indeed, moisture in the bark was shown to prevent high temperatures in the cambium and act as a buffer (Lawes et al., 2011e; Brando et al., 2012), thus investing in inner bark might be an important strategy in Cerrado trees, that have to cope with both the effect of fire and the high water deficit during the dry season.

We found a negative relationship between outer bark thickness and bark density, which might be reflecting the high proportion of corky-bark species. This relationship is expected because the choice of building dense thin barks trades-off with the cost of building light corky and thick barks. Bark density is related to tissue structure, with high-density tissues producing small cells and thick cell walls, and seems to be involved in many different functions, such as protection against pathogens, mechanical support and water storage (Lawes et al., 2011e; Poorter et al., 2014; Rosell et al., 2014). There was also a strong positive relationship between main stem and twig inner and outer bark thickness, as expected in fire-prone environments (Rosell et al., 2015). This functional coordination between twig and stem bark thickness might be adapted for relatively short plants with a canopy exposed to high temperatures during a fire event.

This article is protected by copyright. All rights reserved 
In addition, we showed that the association between tree mortality and bark properties might actually be more related to inner bark traits for Brazilian savanna woody species. Our findings contrast with those of many other authors concluding that total bark thickness provides fire protection independently of its structure (Lawes et al., 2011a; Lawes et al., 2011e; Brando et al., 2012; Pellegrini et al., 2017, Souchie et al. 2017). However, as argued by Vesk (2006), survivorship is not only avoiding mortality, but also being able to resprout efficiently. Indeed, tree height explained both resprouting volume and canopy recovery (i.e., tree recovery), which can be explained by having elevated buds, thus avoiding heating for sufficient time to cause their mortality (Higgins et al., 2000; Bond \& Midgley, 2003; Hoffmann \& Solbrig, 2003). Tree growth also explained topkill, meaning that damage can be avoided through growth. If plants can avoid topkill by growing wide and tall, investing in resprouting would be unnecessary. Notably, growing in height and width is crucial for a plant to achieve thicker bark (Lawes et al., 2011e).

The importance of growth to avoid topkill might also explain why evergreen species suffered lower topkill compared to deciduous and briefly-deciduous species. During the dry season, deciduous species lose their leaves and therefore cease to lose water by transpiration. Evergreen species, on the other hand, are adapted to keep most of their leaves, partially reducing their canopy, but heavily controlling water loss by closing the stomata (Prado et al., 2004; Franco et al., 2005). Brieflydeciduous species lose their leaves for a short period of time, but usually flush new leaves during the dry season. These different strategies during the dry season suggest a whole set of physiological and ecological differences between these groups of plants. Indeed, deciduous plants are shown to have lower SLA combined with higher leaf nutrient concentrations (Scalon et al., 2017), and higher photosynthetic rates (Franco et al., 2005), while evergreen species have the strategy of continuously investing in growth, building leaves with lower SLA and longer lifespan and prioritising resource conservation (Reich et al., 1998; Scalon et al., 2017). Even though we did not find differences in bark traits or resprouting behaviour for different leaf phenology groups, the combination of being topkilled with potentially having less carbon stored (i.e., less reserves in roots) may delay aboveground plant recovery (Landhäusser \& Lieffers, 2002) with evident disadvantages in a long-term scenario. Recent studies are showing that heat-induced cambium damage is the main factor causing xylem dysfunction and post-fire mortality (Bär et al., 2019), and future studies linking bark and hydraulic 
traits in the Cerrado vegetation might elucidate these differences. In addition, future research is needed to specifically investigate the seasonal variation in carbohydrates stored in roots between different phenological groups and its relation to long-term recovery after fire.

This potential advantage of evergreen species over the other two leaf phenology groups might be exclusive for late-dry season fires, when deciduous and briefly-deciduous species have just flushed their new leaves. Natural fires are usually caused by lightning and usually occur early in the wet season (Ramos-Neto \& Pivello, 2000; Pivello et al., 2010). Anthropogenic fires are frequent in the Cerrado, and inappropriate fire management results in land degradation (Pivello, 2011). This humaninduced change in fire seasonality might be especially harmful for briefly-deciduous species (that presented $\sim 31 \%$ of topkill), which may not be able to fully recover. This scenario would result in not only changes in the community structure (Hoffmann \& Moreira, 2002), but also in changes on the balance between different functional groups, with yet unknown consequences on tree community assembly and the overall ecosystem biomass.

In summary, this study shows a suite of different functional traits that defines distinct mechanisms at the species level to survive and regenerate after fire, and highlights the importance of having a diversity of functional strategies to provide fire-tolerance at the community scale. All different ecological strategies displayed seem to be important for both individual survivorship and community assembly in the Cerrado. However, the Cerrado is experiencing profound shifts in natural fire regimes due to land use changes and active fire suppression (Pivello 2011), which may lead to changes in plant community and, in the long term, jeopardize the diversity of Cerrado fire-tolerant strategies that this study reveals.

\section{Acknowledgments}

We thank Benjamin Blonder for useful comments on previous versions of this manuscript.

\section{Authors' contribution}

MCS, IO conceived the idea, questions and hypotheses; MCS, IO, BSM and BHMJr developed study design and methodology; MCS and WJSC collected the data; MCS and FMCBD analysed the data;

This article is protected by copyright. All rights reserved 
MCS and IO led the writing of the manuscript, IO got the funding, and all authors critically contributed to the drafts and gave final approval for publication.

\section{Data Accessibility}

All data used in this manuscript are present in the manuscript and its supporting information (Appendix S11). Data is also available at TRY Plant Trait database (https://www.trydb.org/TryWeb/Home.php).

\section{References}

Abràmoff, M. D. et al. 2004. Image processing with ImageJ. Biophotonics International 117: 36-43. Agrawal, A. A. 2007. Macroevolution of plant defense strategies. Trends Ecol. Evol. 22: 103-109. https://doi.org/10.1016/j.tree.2006.10.012

Aschan, G. and Pfanz, H. 2003. Non-foliar photosynthesis - a strategy of additional carbon acquisition. Flora 1982: 81-97. https://doi.org/10.1078/0367-2530-00080

Bär, A. S.T. et al. 2019. Fire effects on tree physiology. New Phytol. https://doi.org/10.1111/nph.15871

Bond, W. J. et al. 2012. Which trees dominate in savannas? The escape hypothesis and eucalypts in northern Australia. Austral Ecol. 37: 678-685. https://doi.org/10.1111/j.14429993.2011.02343.x

Bond, W. J. and Keeley, J. E. 2005. Fire as a global 'herbivore': the ecology and evolution of flammable ecosystems. Trends Ecol. Evol.20: 387-394. https://doi.org/10.1016/j.tree.2005.04.025

Bond, W. J. and Midgley, J. J. 2003. The evolutionary ecology of sprouting in woody plants. Int. J. Plant Sci. 164: S103-S114. https://doi.org/10.1086/374191

Brando, P. M. et al. 2012. Fire-induced tree mortality in a neotropical forest: the roles of bark traits, tree size, wood density and fire behavior. Glob. Change Biol. 18: 630-641. https://doi.org/10.1111/j.1365-2486.2011.02533.x

This article is protected by copyright. All rights reserved 
Burrows, G. 2002. Epicormic strand structure in Angophora, Eucalyptus and Lophostemon (Myrtaceae)- implications for fire resistance and recovery. New Phytol. 153: 111-131. https://doi.org/10.1046/j.0028-646X.2001.00299.x

Burrows, G. and Chisnall, L. 2016. Buds buried in bark: the reason why Quercus suber (cork oak) is an excellent post-fire epicormic resprouter. Trees- Struct. Funct. 30: 241-254. https://doi.org/10.1007/s00468-015-1293-1

Burrows, G., et al. 2010. A wide diversity of epicormic structures is present in Myrtaceae species in the northern Australian savanna biome-implications for adaptation to fire. Aust. J. Bot. 58: 493-507. https://doi.org/10.1071/BT10107

Cardoso, A.W. et al. 2016. Winners and losers: tropical forest tree seedling survival across a West African forest-savanna transition. Ecol Evol. 6: 3417-3429. https://doi.org/10.1002/ece3.2133

Cernusak, L.A. and Cheesman, A. W. 2015. The benefits of recycling: how photosynthetic bark can increase drought tolerance. New Phytol. 208: 995-997. https://doi.org/10.1111/nph.13723

Cernusak, L.A. and Hutley, L. B. 2011. Stable isotopes reveal the contribution of corticular photosynthesis to growth in branches of Eucalyptus miniata. Plant Physiol. 155: 515-523. https://doi.org/10.1104/pp.110.163337

Charles-Dominique, T. et al. 2015. Bud protection: a key trait for species sorting in a forest-savanna mosaic. New Phytol. 207: 1052-1060. https://doi.org/10.1111/nph.13406

Charrad, M., et al. 2014. NbClust: an R package for determining the relevant number of clusters in a data set. J.Stat. Softw. 61: 1-36.

Clarke, P. J. et al. 2013. Resprouting as a key functional trait: how buds, protection and resources drive persistence after fire. New Phytol. 197: 19-35. https://doi.org/10.1111/nph.12001

Coutinho, L. M. 1990. Fire in the ecology of the Brazilian cerrado. Fire in the tropical biota. Berlin, Heidelberg. Springer. https://doi.org/10.1007/978-3-642-75395-4_6

Dantas, V. d. L. and Pausas, J. G. 2013. The lanky and the corky: fire-escape strategies in savanna woody species. J. Ecol. 101: 1265-1272. https://doi.org/10.1111/1365-2745.12118

Drewa, P. B. et al. 2002. Fire effects on resprouting of shrubs in headwaters of southeastern longleaf pine savannas. Ecol. 83: 755-767. https://doi.org/10.1890/00129658(2002)083[0755:FEOROS]2.0.CO;2

This article is protected by copyright. All rights reserved 
Driscoll, D.A., et al. 2010. Fire management for biodiversity conservation: key research questions and our capacity to answer them. Biol. Cons., 143: 1928-1939. https://doi.org/10.1016/j.biocon.2010.05.026

Franco, A. C. et al. 2005. Leaf functional traits of Neotropical savanna trees in relation to seasonal water deficit. Trees-Struct. Funct. 19: 326-335. https://doi.org/10.1007/s00468-004-0394-z

Genuer, R. et al. 2010. Variable selection using random forests. Pattern Recogni. Lett. 31: 2225-2236. https://doi.org/10.1016/j.patrec.2010.03.014

Genuer, R. et al. 2015. VSURF: An R Package for Variable Selection Using Random Forests. R Journal 7.

Gignoux, J. et al. 1997. Alternative fire resistance strategies in savanna trees. Oecologia 110: 576583. https://doi.org/10.1007/s004420050198

Glitzenstein, J. S. et al. 1995. Effects of fire regime and habitat on tree dynamics in north Florida longleaf pine savannas. Ecol. Monograph 65: 441-476. https://doi.org/10.2307/2963498

Higgins, S. I. et al. 2000. Fire, resprouting and variability: a recipe for grass-tree coexistence in savanna. J. Ecol. 88: 213-229. https://doi.org/10.1046/j.1365-2745.2000.00435.x

Hoffmann, W. A. et al. 2009. Tree topkill, not mortality, governs the dynamics of savanna-forest boundaries under frequent fire in central Brazil. Ecol. 90: 1326-1337. https://doi.org/10.1890/08-0741.1

Hoffmann, W. A. et al. 2012. Ecological thresholds at the savanna-forest boundary: how plant traits, resources and fire govern the distribution of tropical biomes. Ecol. Lett. 15: 759-768. https://doi.org/10.1111/j.1461-0248.2012.01789.x

Hoffmann, W. A. and Moreira, A. G. 2002. The role of fire in population dynamics of woody plants. The Cerrados of Brazil. Ecology and Natural History of a Neotropical Savanna. New York. Columbia University Press, pp. 159-177.

Hoffmann, W. A. and Solbrig, O. T. 2003. The role of topkill in the differential response of savanna woody species to fire. For. Ecol. Manage. 180: 273-286. https://doi.org/10.1016/S03781127(02)00566-2

Jackson, J. F. et al. 1999. Allometry of constitutive defense: a model and a comparative test with tree bark and fire regime. Am. Nat. 153: 614-632. https://doi.org/10.1086/303201

This article is protected by copyright. All rights reserved 
Keeley, J. E. et al. 2011. Fire as an evolutionary pressure shaping plant traits. Trends Plant Sci. 16: 406-411. https://doi.org/10.1016/j.tplants.2011.04.002

Knox, K. J. and Clarke, P. J. 2011. Fire severity and nutrient availability do not constrain resprouting in forest shrubs. Plant Ecol. 212: 1967-1978. https://doi.org/10.1007/s11258-011-9956-5

Lamont, B. B. and Wiens, D. 2003. Are seed set and speciation rates always low among species that resprout after fire, and why? Evol. Ecol. 17: 277-292. https://doi.org/10.1023/A:1025535223021

Landhäusser, S. M. and Lieffers, V. J. 2002. Leaf area renewal, root retention and carbohydrate reserves in a clonal tree species following above-ground disturbance. J. Ecol. 90: 658-665. https://doi.org/10.1046/j.1365-2745.2002.00699.x

Lawes, M. J. et al. 2011a. How do small savanna trees avoid stem mortality by fire? The roles of stem diameter, height and bark thickness. Ecosphere 2: 1-13. https://doi.org/10.1890/ES10-00204.1

Lawes, M. J. et al. 2011b. Bark thickness determines fire resistance of selected tree species from fireprone tropical savanna in north Australia. Plant Ecol. 212: 2057-2069.

https://doi.org/10.1007/s11258-011-9954-7

Lawes, M. J. and Clarke, P. J. 2011. Ecology of plant resprouting: populations to community responses in fire-prone ecosystems. Plant Ecol. 212: 1937-1943. https://doi.org/10.1007/s11258-011-9994-z

Lawes, M. J. et al. 2013. Costs and benefits of relative bark thickness in relation to fire damage: a savanna/forest contrast. J. Ecol. 101: 517-524. https://doi.org/10.1111/1365-2745.12035

Lê, S. et al. 2008. FactoMineR: an R package for multivariate analysis. J. Stat. Softw. 25: 1-18.

Lehmann, C. E. et al. 2011. Deciphering the distribution of the savanna biome. New Phytol. 191: 197209. https://doi.org/10.1111/j.1469-8137.2011.03689.x

Niklas, K. J. 1999. The mechanical role of bark. Am. J. Bot. 86: 465-469. https://doi.org/10.2307/2656806

Pausas, J. G. et al. 2018. Unearthing belowground bud banks in fire-prone ecosystems. New Phytol. 217: 1435-48. https://doi.org/10.1111/nph.14982

This article is protected by copyright. All rights reserved 
Pellegrini, A. F. et al. 2017. Convergence of bark investment according to fire and climate structures ecosystem vulnerability to future change. Ecol. Lett. 20: 307-316. https://doi.org/10.1111/ele.12725

Perez-Harguindeguy, N. et al. 2013. New handbook for standardised measurement of plant functional traits worldwide. Aust. J. Bot. 61: 167-234. https://doi.org/10.1071/BT12225

Pivello, V. R. 2011. The use of fire in the Cerrado and Amazonian rainforests of Brazil: past and present. Fire Ecol. 7: 24-39. https://doi.org/10.4996/fireecology.0701024

Pivello, V. R. et al. 2010. Effect of fires on soil nutrient availability in an open savanna in Central Brazil. Plant Soil 337: 111-123. https://doi.org/10.1007/s11104-010-0508-X

Poorter, L. et al. 2014. Bark traits and life-history strategies of tropical dry-and moist forest trees. Funct. Ecol. 28: 232-242. https://doi.org/10.1111/1365-2435.12158

Prado, C. H. B. A. et al. 2004. Seasonal leaf gas exchange and water potential in a woody cerrado species community. Braz. J. Plant Physiol. 16: 7-16. http://dx.doi.org/10.1590/S167704202004000100002

Quinn, G. P. and Keough, M. J. 2002. Experimental design and data analysis for biologists. Cambridge University Press.

R Core Team. 2017. R: A language and environment for statistical computing. Vienna, Austria.

Ramos-Neto, M. B. and Pivello, V. R. 2000. Lightning fires in a Brazilian savanna National Park: rethinking management strategies. Environ. Manage. 26: 675-684. https://doi.org/10.1007/s002670010124

Reich, P. et al. 1998. Leaf structure (specific leaf area) modulates photosynthesis-nitrogen relations: evidence from within and across species and functional groups. Funct. Ecol. 12: 948-958. https://doi.org/10.1046/j.1365-2435.1998.00274.X

Romero, C and Bolker B. M. 2008. Effects of stem anatomical and structural traits on responses to stem damage: an experimental study in the Bolivian Amazon. Can. J. For. Res. 38: 611-618. https://doi.org/10.1139/X07-205

Rosell, J. A. 2016. Bark thickness across the angiosperms: more than just fire. New Phytol. 211: 90102. https://doi.org/10.1111/nph.13889

This article is protected by copyright. All rights reserved 
Rosell, J. A et al. 2015. Bark ecology of twigs vs. main stems: functional traits across eighty-five species of angiosperms. Oecologia 178: 1033-1043. https://doi.org/10.1007/s00442-015-33075

Rosell, J. A. et al. 2014. Bark functional ecology: evidence for tradeoffs, functional coordination, and environment producing bark diversity. New Phytol. 201: 486-497. https://doi.org/10.1111/nph.12541

Scalon, M. C. et al. 2017. Influence of long-term nutrient manipulation on specific leaf area and leaf nutrient concentrations in savanna woody species of contrasting leaf phenologies. Plant Soil 421: 233-244. https://doi.org/10.1007/s11104-017-3437-0

Schafer, J. L. et al. 2015. Relative bark thickness is correlated with tree species distribution along a fire frequency gradient. Fire Ecol. 11: 74-87. https://doi.org/10.4996/fireecology.1101074

Scholz, F. G. et al. 2007. Biophysical properties and functional significance of stem water storage tissues in Neotropical savanna trees. Plant Cell Environ. 30: 236-248. https://doi.org/10.1111/j.1365-3040.2006.01623.x

Souchie, F. F. et al. 2017. Post-fire resprouting strategies of woody vegetation in the Brazilian savanna. Acta Bot. Bras. 31: 260-266. http://dx.doi.org/10.1590/0102-33062016abb0376

Vandegehuchte, M. W. et al. 2015. Woody tissue photosynthesis in trees: salve on the wounds of drought? New Phytol. 208: 998-1002. https://doi.org/10.1111/nph.13599

Vesk, P. A. 2006. Plant size and resprouting ability: trading tolerance and avoidance of damage? J. Ecol. 94: 1027-1034. https://doi.org/10.1111/j.1365-2745.2006.01154.x

Vesk, P. A and Westoby, M. 2004a. Funding the bud bank: a review of the costs of buds. Oikos 106: 200-208. https://doi.org/10.1111/j.0030-1299.2004.13204.x

Vesk, P. A. and Westoby, M. 2004b. Sprouting by plants: the effects of modular organization. Funct. Ecol. 18: 939-945. https://doi.org/10.1111/j.0269-8463.2004.00899.x

Zar, J. H. 1999. Biostatistical analysis. Pearson Education India.

This article is protected by copyright. All rights reserved 
Table 1. Bark traits averages $( \pm \mathrm{sd})$ for each bud protection class. Protection increases from 0 to 3. Analysis of variance followed by post hoc Tukey tests for unequal sample sizes. Different letters denote significant statistical differences $(P<0.05)$.

Bark traits

Bud protection class

Stem total relative bark thickness $(\%)$

0

17.70

$27.71 \mathbf{a} \quad 30.88 \mathbf{a b} \quad 41.48 \mathbf{b}$

(11.97)

(8.35)

Stem outer relative bark thickness (\%)

Stem inner relative bark thickness (\%)

$\begin{array}{llll}8.50 \mathbf{a} & 14.85 \mathbf{a} & 12.28 \mathbf{a} & 31.35 \mathbf{b}\end{array}$

Stem bark water content (\%)

$\begin{array}{llll}(5.24) & (14.00) & (9.06) & (6.20)\end{array}$

Stem inner relative bark thickness $(\%)$ $17.80 \mathbf{a}$ $12.85 \mathbf{a b} \quad 18.60 \mathbf{a} \quad 10.13 \mathbf{b}$

(6.50)

$44.59 \mathbf{a}$

$32.99 \mathbf{a}$

$46.64 \mathbf{a}$

$19.91 b$

(18.11)

(17.83)

(14.18)

Twig relative bark thickness (\%)

$32.55 \mathbf{a}$

$40.26 \mathbf{a}$

$36.11 \mathbf{a}$ $38.47 \mathbf{a}$

(9.28)

(8.07)

(7.08)

(16.49)

Stem inner bark density $\left(\mathrm{g} \mathrm{mm}^{-3}\right)$

$0.49 \mathbf{a}$

$0.53 \mathrm{a}$

$0.45 \mathbf{a}$

$0.46 \mathbf{a}$

(0.16)

(0.10)

$(0.05)$

(0.08)

Stem outer bark density $\left(\mathrm{g} \mathrm{mm}^{-3}\right)$

\section{$0.50 \mathbf{a}$}

$0.39 \mathbf{a}$

$0.41 \mathbf{a}$

$0.27 \mathbf{a}$

$(0.17)$

$(0.16)$

$(0.14)$

$(0.11)$

This article is protected by copyright. All rights reserved 
Table 2. Pearson's correlation (r and $P$-values) between bark and plant traits. Significant correlations ( $P$-values lower than 0.05$)$ shown in bold. Total relative bark thickness (TBT), inner relative bark thickness (IBT) and outer relative bark thickness (OBT), inner bark density (IBD), outer bark density (OBD), and bark water content (BWC).

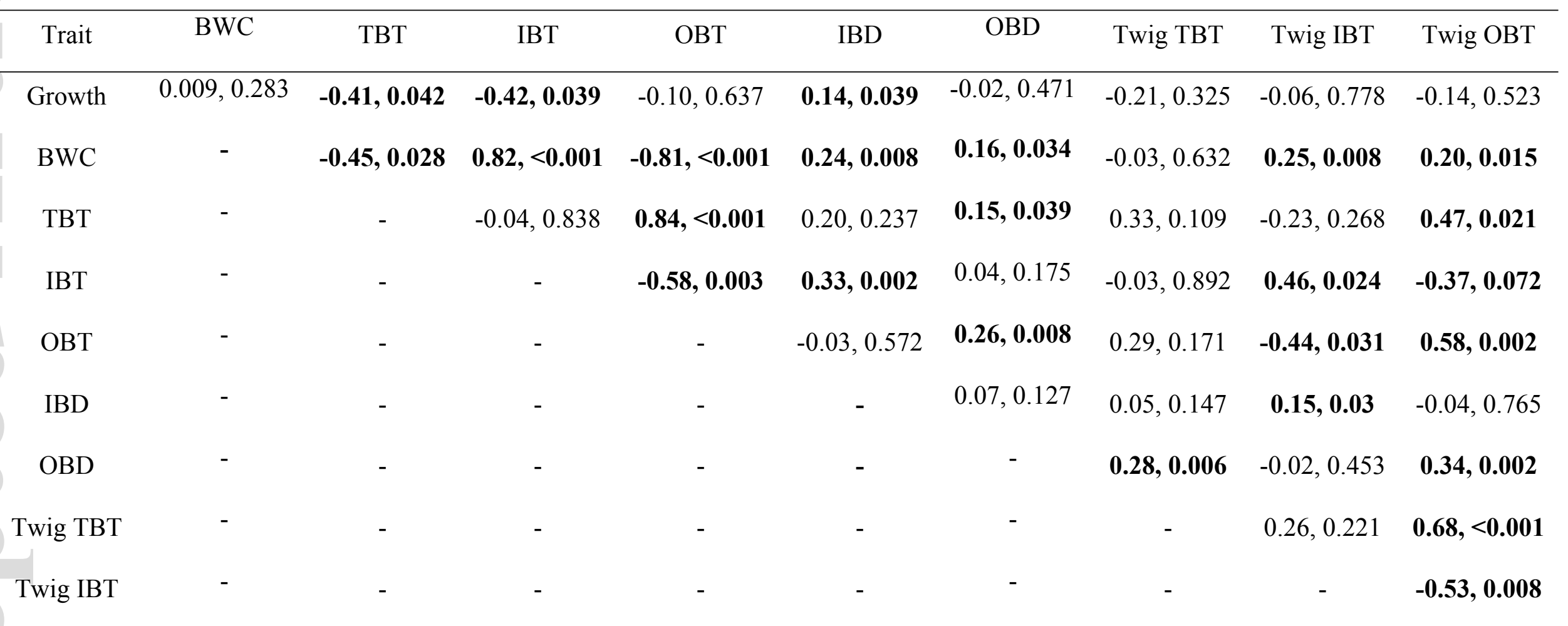


Table 3. Variable Importance score of the Random Forest models generated for each variable selection: Topkill, Tree mortality, Canopy recovery, and Resprout volume. Selected variables are shown in bold. Variables abbreviations are as follow: $\mathrm{BD}=$ bark density, $\mathrm{BWC}=$ bark water content, $\mathrm{DBH}=$ diameter at breast height, $\mathrm{IBD}=$ inner bark density, $\mathrm{IBT}=$ inner bark thickness, $\mathrm{IBWC}=$ inner bark water content, $\mathrm{OBD}=$ outer bark density, $\mathrm{OBT}=$ outer bark thickness, $\mathrm{OBWC}=$ outer bark water content, SLA = specific leaf area, TBT = total bark thickness, Twig_IBT = twig inner bark thickness, Twig_OBT $=$ twig outer bark thickness, Twig_TBT $=$ twig total bark thickness, Type $=$ phenological type, $\mathrm{WD}=$ wood density.

\begin{tabular}{ccccc}
\hline \multirow{2}{*}{ Traits } & \multicolumn{4}{c}{ Variable Importance score } \\
\cline { 2 - 5 } & Topkill & Tree & Canopy & Resprouting \\
& & mortality & recovery & volume \\
\hline BD & -8.30 & -0.41 & -5.74 & 0.23 \\
Bud type & $\mathbf{5 . 1 9}$ & -0.90 & -1.85 & -0.41 \\
BWC & 8.65 & -0.42 & -0.63 & 0.17 \\
DBH & 0.31 & -0.63 & $\mathbf{5 4 . 5 5}$ & -0.96 \\
Growth & $\mathbf{9 . 9 0}$ & -0.06 & -7.02 & -0.19 \\
Height & -9.03 & -4.57 & $\mathbf{2 2 . 4 3}$ & $\mathbf{0 . 5 0}$ \\
IBD & -14.14 & $\mathbf{2 . 9 0}$ & -5.25 & -0.08 \\
IBT & 1.61 & $\mathbf{0 . 8 4}$ & 1.05 & 0.39 \\
IBWC & -3.73 & -0.06 & 5.78 & -0.16 \\
OBD & -7.11 & -0.75 & -6.74 & 0.19 \\
OBT & 4.36 & -0.37 & -2.70 & -0.06 \\
OBWC & $\mathbf{8 . 6 5}$ & -1.14 & -5.89 & 0.14 \\
Phenology & $\mathbf{4 . 3 6}$ & -0.07 & -0.03 & 0.04 \\
SLA & -2.45 & -4.27 & $\mathbf{9 . 8 2}$ & $\mathbf{0 . 8 9}$ \\
TBT & 9.90 & -1.40 & -2.93 & 0.34 \\
Twig IBT & 1.61 & -0.40 & -4.53 & -0.43 \\
Twig OBT & -4.00 & -0.17 & 1.01 & 0.14 \\
Twig TBT & 0.09 & -0.81 & -3.59 & $\mathbf{1 . 8 2}$ \\
WD & 5.19 & -1.31 & -9.42 & -0.11 \\
\hline
\end{tabular}

This article is protected by copyright. All rights reserved 


\section{Figure legends}

Figure 1. Epicormic buds from twigs of 12 out of the 24 Cerrado species used in this study (Table S1) divided into bud protection categories: 0 for completely exposed buds; 1 for emerging buds but protected meristem; 2 for buds allocated inside depressions in the bark; and 3 for buds completely protected under the bark. Left to right, depicted species are 0 - Annona coriacea, Dipteryx alata, Tacchigali aurea; 1 - Hymenaea stignocarpa, Byrsonima pachyphylla, Qualea grandiflora; 2 Byrsonima coccolobifolia, Ouratea hexasperma, Qualea multiflora; 3 - Davilla elliptica, Kielmeyera rubriflora, Curatella americana. Scales $5 \mathrm{~mm}$. Red arrows are pointing to the bud.

Figure 2. Correspondence analysis of bud protection and tree post-fire responses summarizing information of 263 individuals from 24 Cerrado species. Bud protection categories were: 0 for completely exposed buds; 1 for emerging buds but protected meristem; 2 for buds allocated inside depressions in the bark; and 3 for buds completely protected under the bark. Post-fire responses were: Epicormic (apical and stem resprouting only); Hypogeal (basal and underground resprouting only); Epi+Hypogeal (a combination of epicormic and hypogeal resprouting together); Topkill and Mortality. Details of the analysis are available in Appendix S5.

Figure 3. Principal component analysis of bark and plant traits. Scores calculated per species (24 species) classified into three different groups generated by cluster analysis of 14 fire-related traits (groups A, B and C). Details of the analysis (loadings) are available in Appendix S9. Variables abbreviations are as follow: $\mathrm{TBT}=$ total relative bark thickness, $\mathrm{BWC}=$ bark water content, Growth $=$ annual growth rate, IBT $=$ inner relative bark thickness, OBT $=$ outer relative bark thickness, SLA = specific leaf area, $\mathrm{DBH}=$ diameter at breast height, $\mathrm{WD}=$ wood density, $\mathrm{IBD}=$ inner bark density, OBD $=$ outer bark density, Twig_TBT $=$ twig total relative bark thickness, Twig_IBT $=$ twig inner relative bark thickness, Twig_OBT $=$ twig outer relative bark thickness.

Figure 4. Comparison between the three different functional groups in the Cerrado (evergreen, briefly-deciduous and deciduous) in relation to (a) main stem total relative bark thickness, (b) twig total relative bark thickness, (c) total bark density, (d) percentage of canopy recover, (e) maximum 
resprouting volume (MRV), (f) number of shoots that resprouted, (g) percentage of species with epicormic, (h) hypogeal and (i) epicormic and hypogeal resprout together, (j) percentage of topkilled individuals, (k) growth rate, and (l) specific leaf area. Different letters denote statistical difference according to ANOVA or Kruskal-Wallis tests.

This article is protected by copyright. All rights reserved 


\section{Supporting information}

Appendix S1. Species list and classification according to leaf phenology and bud protection. Appendix S2. Photos of the burned area during and after fire.

Appendix S3. Photos representing the four resprouting categories.

Appendix S4. Average and range of measured traits and surviving strategies.

Appendix S5. Correspondence analysis summary.

Appendix S6. Boxplots of resprouting strategies according to bud protection classification.

Appendix S7. Cluster analysis.

Appendix S8. Boxplots of resprouting strategies according to groups generated by the cluster analysis.

Appendix S9. Abbreviations and loadings of the first two principal components.

Appendix S10. Random Forest variable selection.

Appendix S11. Primary data used for the analyses.

This article is protected by copyright. All rights reserved 

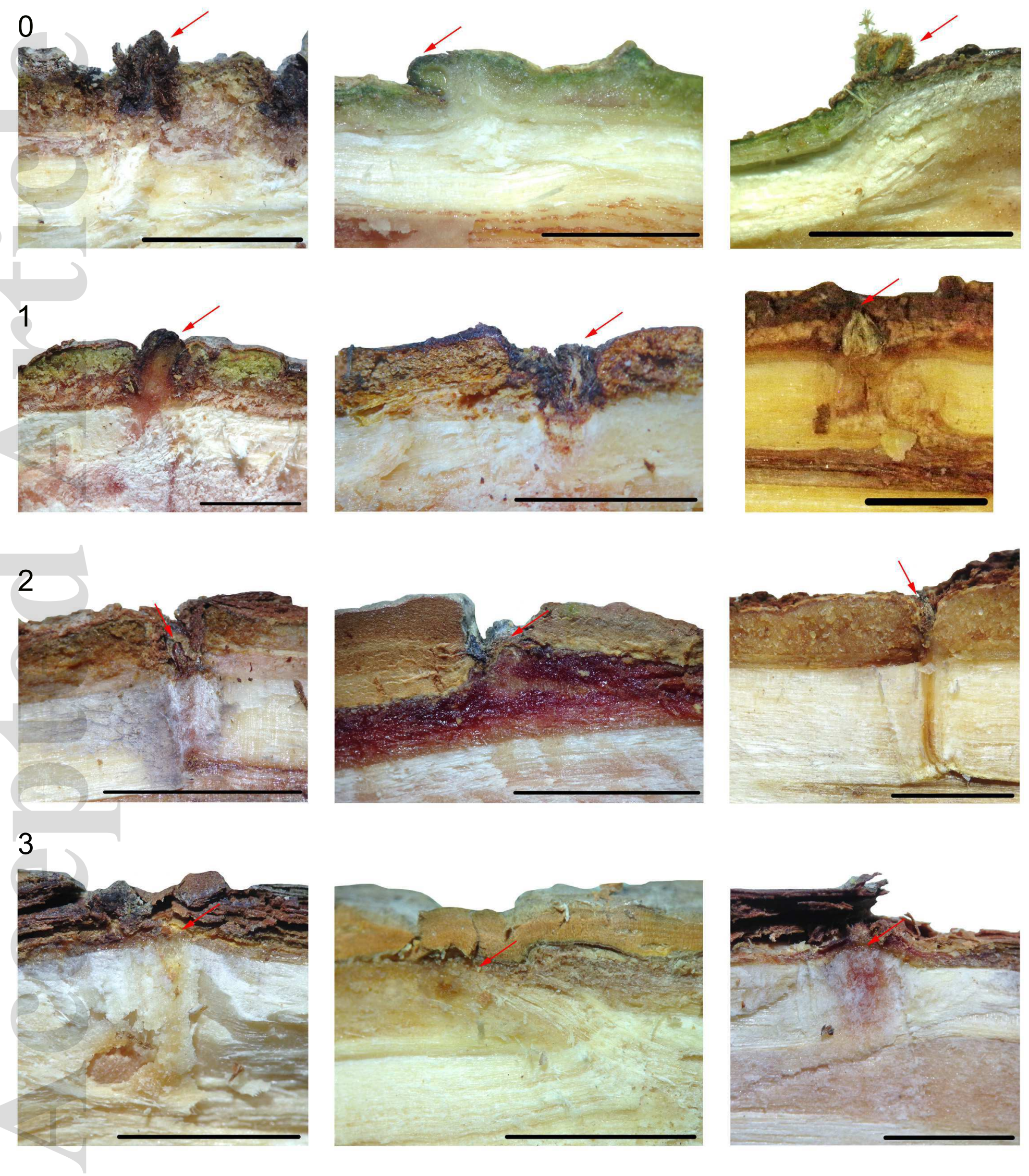

jvs_12823_f1.eps

This article is protected by copyright. All rights reserved 


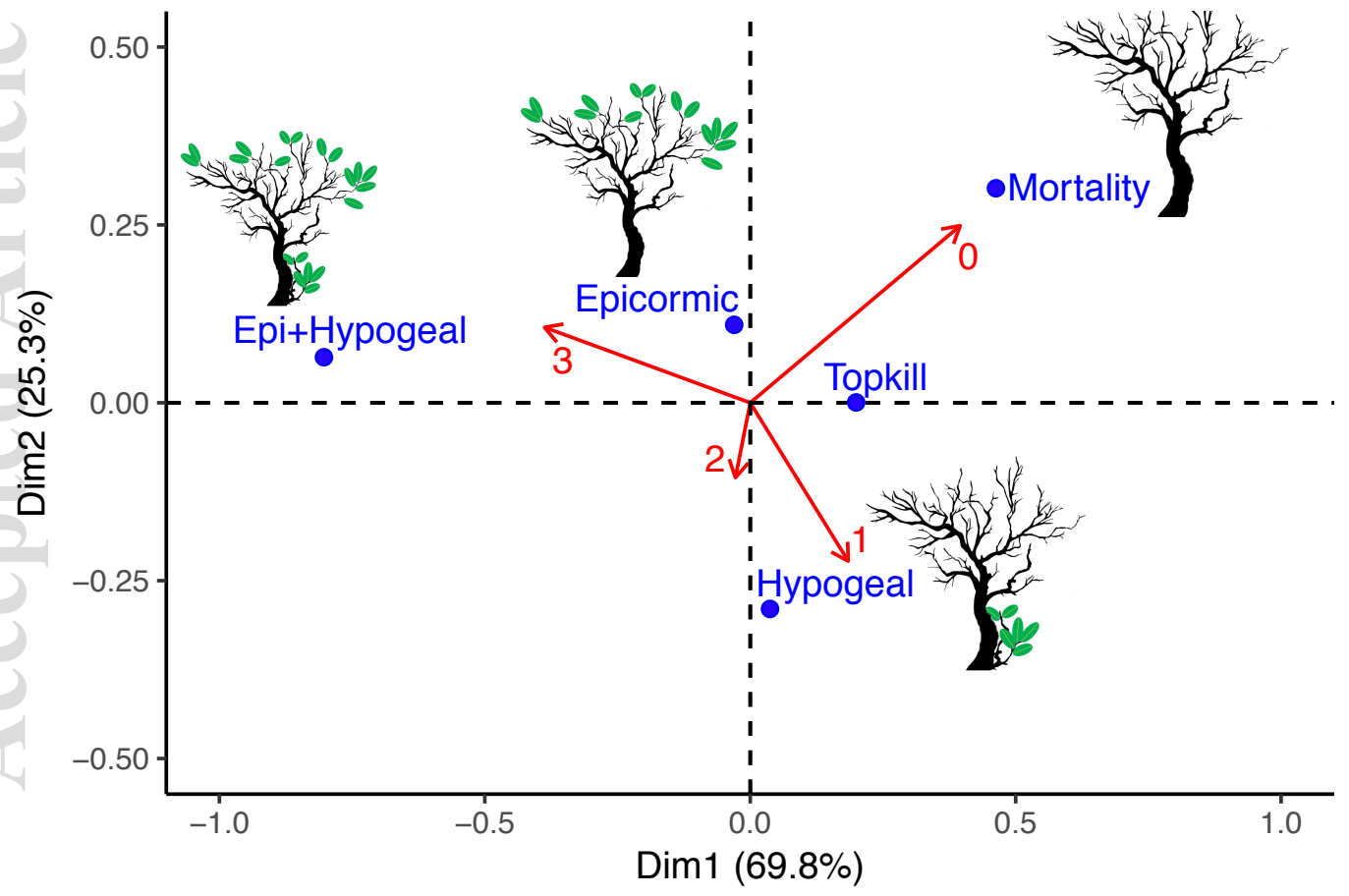




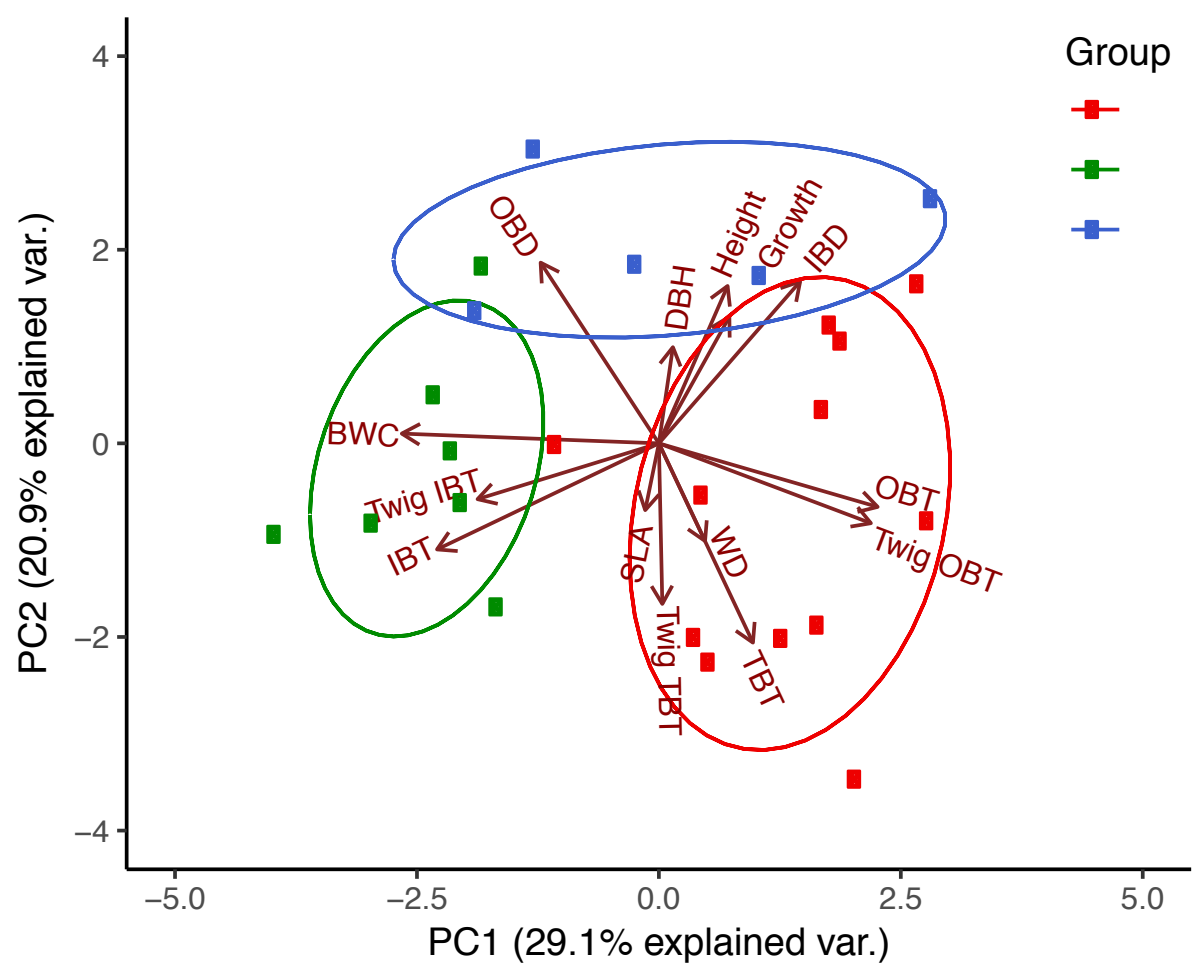


Tree topkill (\%)

Epicormic resprout (\%)

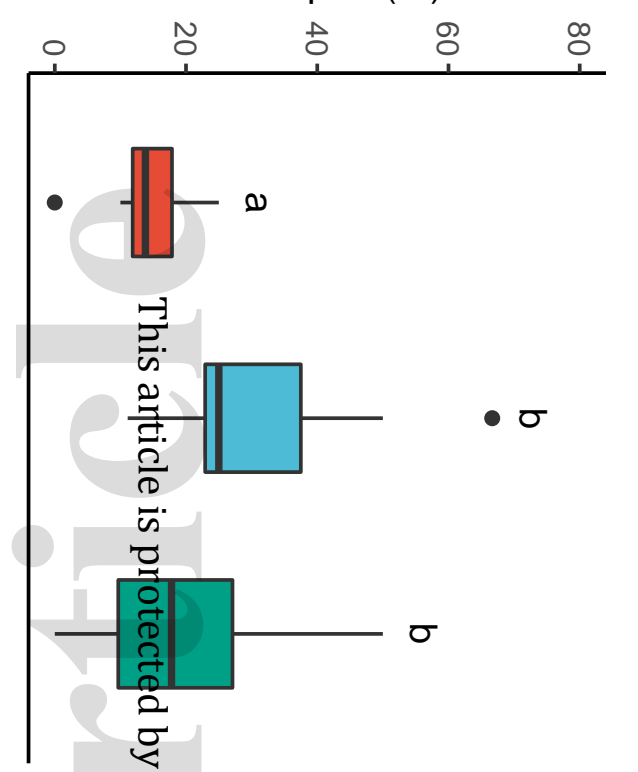

द्वेrowth (mm year $\left.{ }^{-1}\right)$

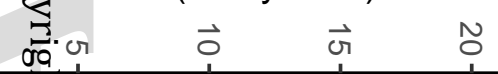

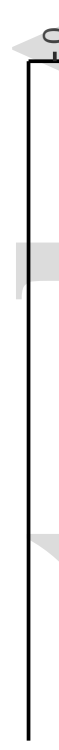
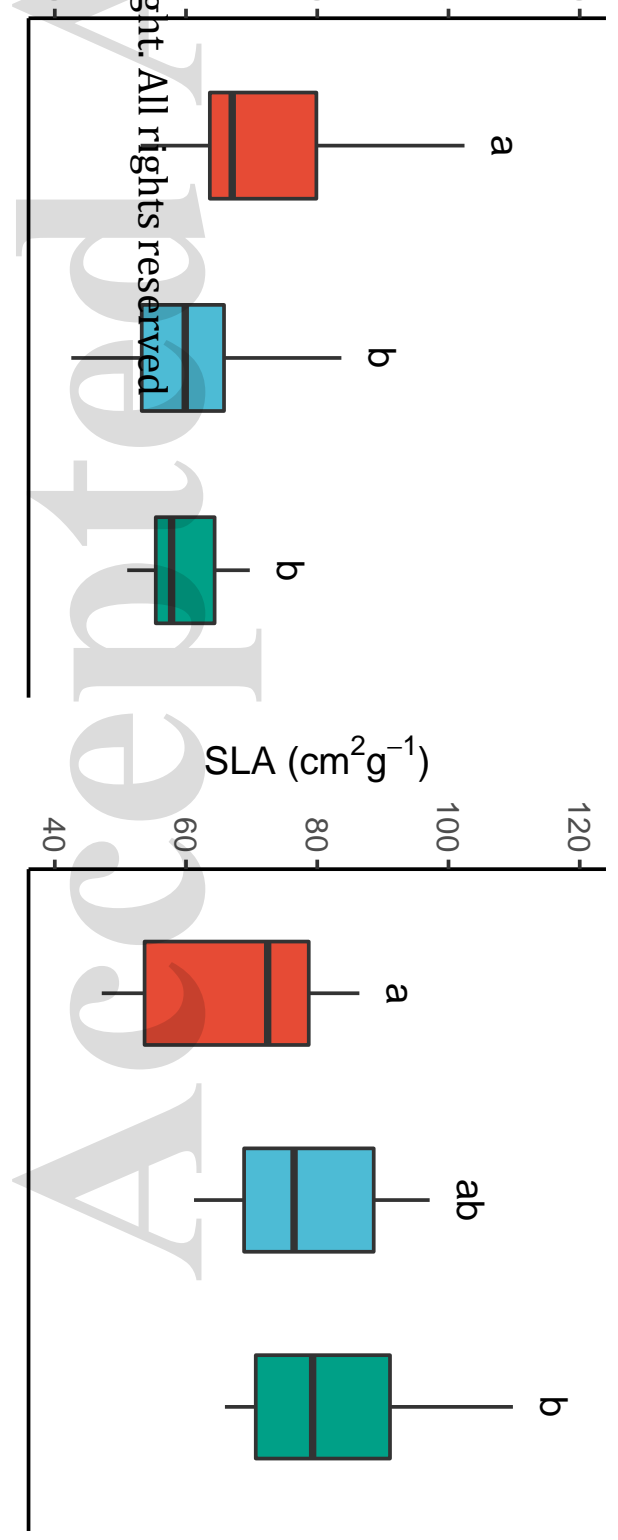

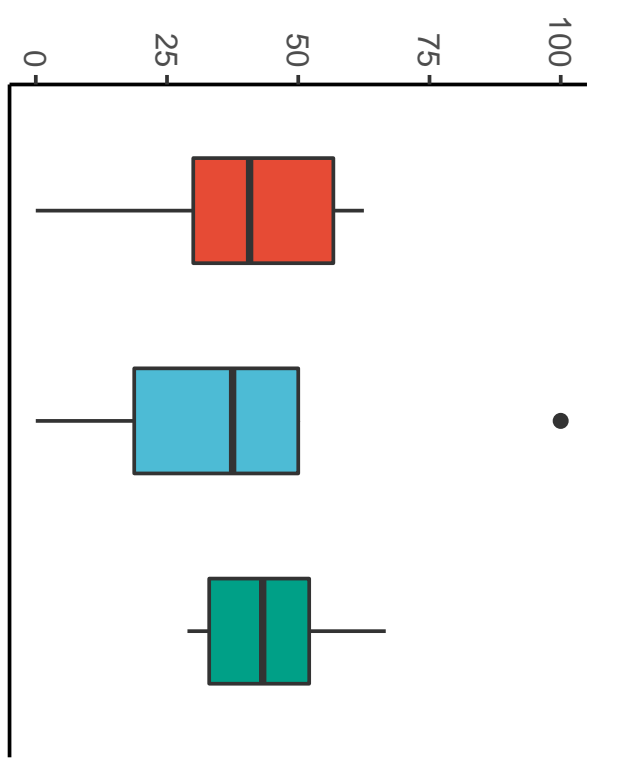

Hypogeal resprout (\%)

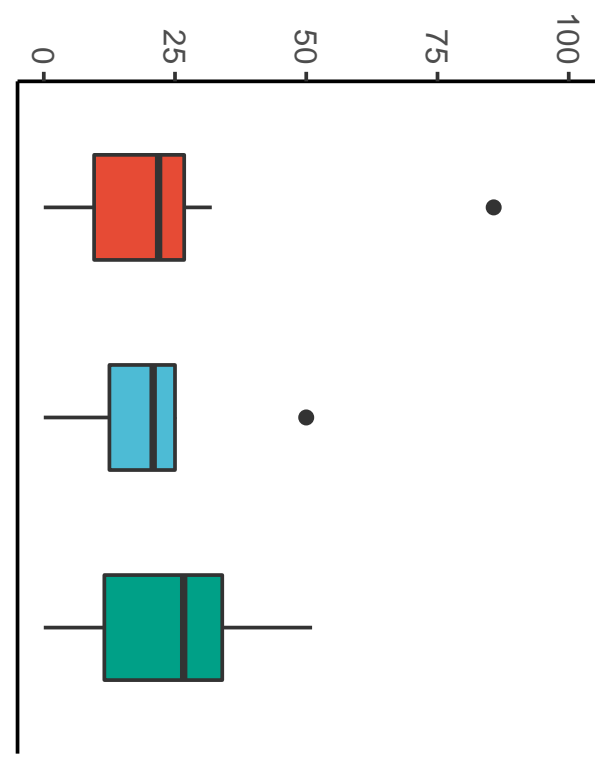

Epi + Hypogeal resprout (\%)

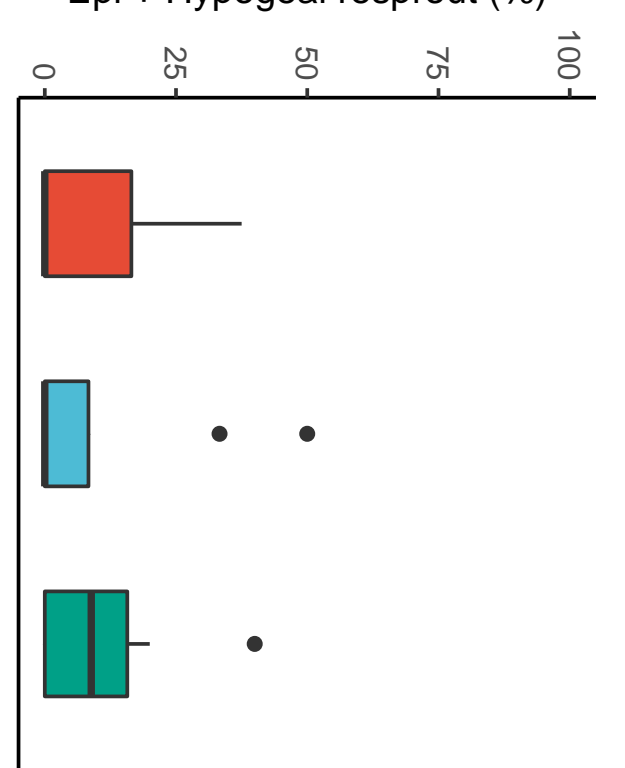

Canopy recover (\%)

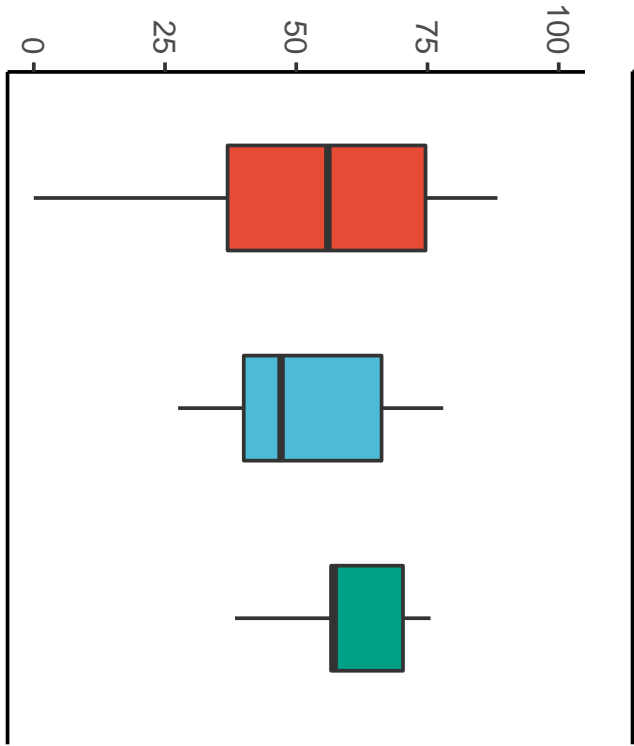

Bark thickness
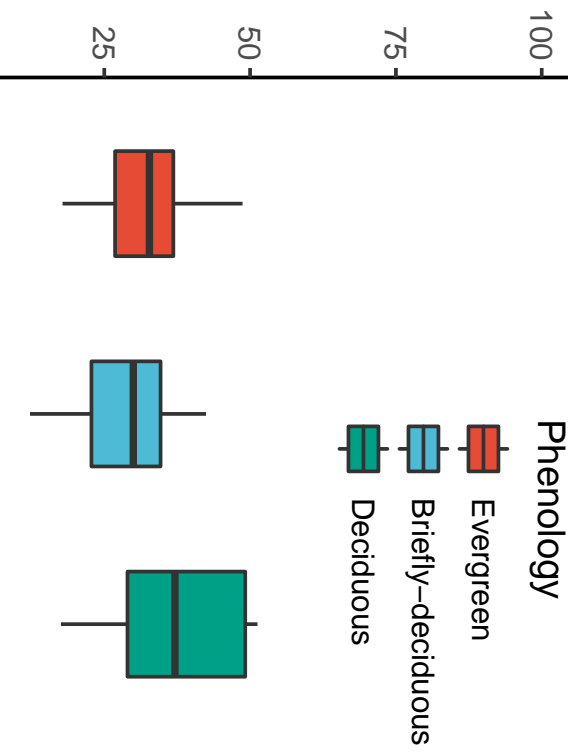

Bark thickness twig (\%)

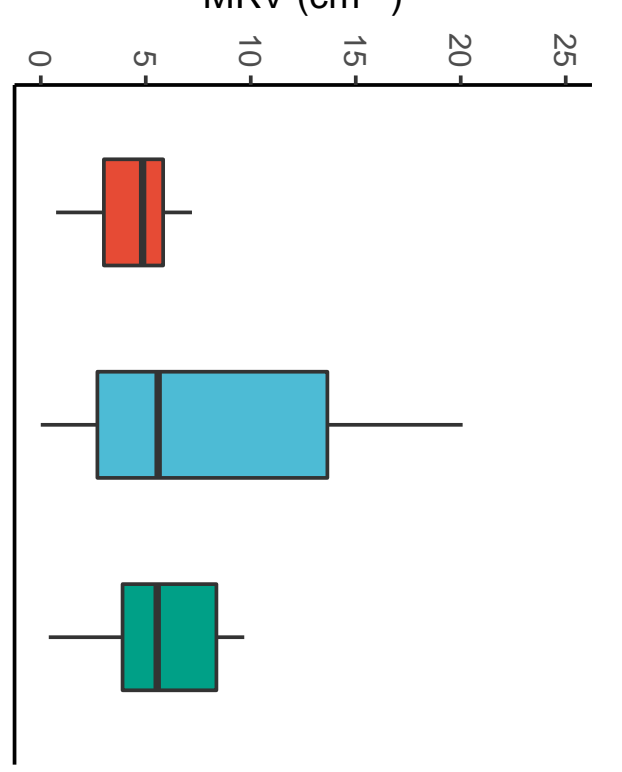

N
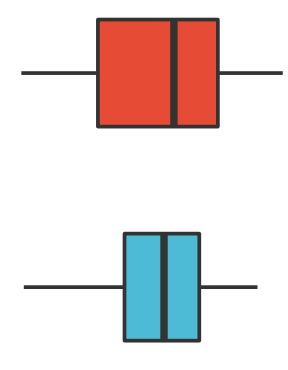

Number of shoots

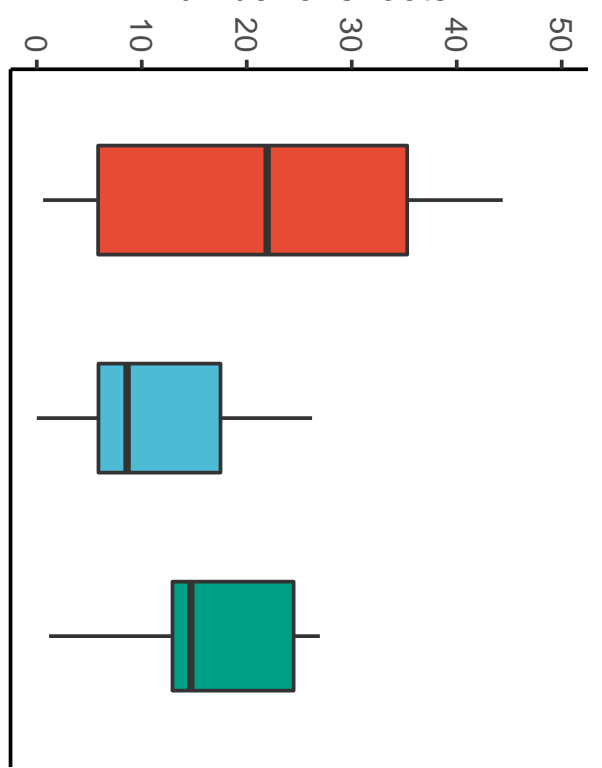

Total bark density stem $\left(\mathrm{g} \mathrm{cm}^{-3}\right)$

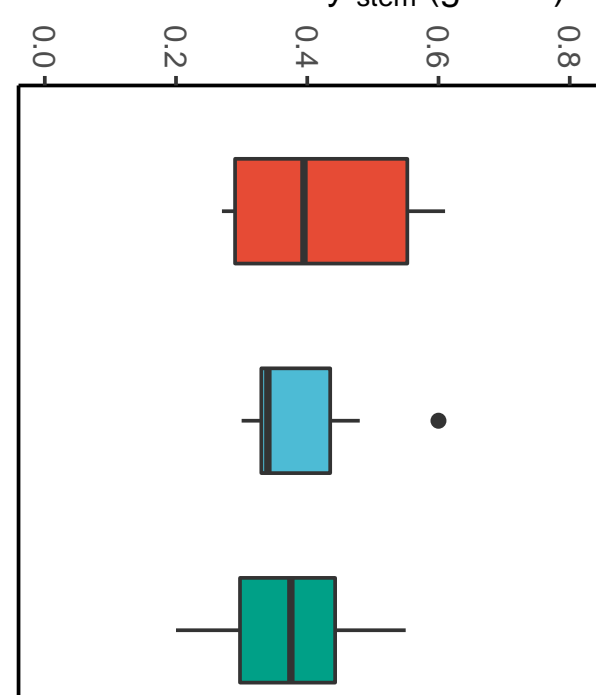

